\title{
Evaluation of Efficiency and Response of Quinoa Plant to Nitrogen Fertilization levels
}

\author{
Abdulrahman M. Almadini', Ayman E. Badran² and Abdullah M. Algosaibi ${ }^{1}$
}

\author{
${ }^{I}$ Department of Agricultural Environment \& Natural Resources, College of Agricultural \& Food \\ Sciences, King Faisal University, Saudi Arabia. \\ ${ }^{2}$ Department of Genetic Resources, Desert Research Center, Cairo, Egypt.
}

\section{Received: 30 July 2019/ Accepted 25 Sept. 2019 / Publication date: 10 Oct. 2019}

\begin{abstract}
A field experiment was conducted to evaluate the response of the quinoa yield to nitrogen $(\mathrm{N})$ fertilization, the nitrogen use efficiency (NUE) as well as the correlation coefficient to determine the important traits that contribute in determining the productivity of quinoa crop. Three levels of $\mathrm{N}$ fertilizer (i.e., 0,80 and $160 \mathrm{~kg} \mathrm{~N}^{-1}$ ) were used and laid out in a randomized complete block design with four replicates. The results showed that all tested characteristics were significantly increased with increasing $\mathrm{N}$ fertilizer treatments showing grain yields per plant varying from 2.48 to $18.08 \mathrm{~g} \mathrm{plant}^{-1}$ and grain yields per hectare ranging from 101.23 to $770.2 \mathrm{~kg} \mathrm{ha}^{-1}$. In contrast, NUE was significantly reduced with increasing $\mathrm{N}$ fertilizer rates from 5.52 to 4.31 . The results indicated that there were significant effects of treatments on some chemical components in grains at 0 and $160 \mathrm{~kg} \mathrm{~N} \mathrm{ha}^{-1}$ (i.e., 14.81 and $17.13 \%$ protein respectively); $\mathrm{N}$, phosphorus $(\mathrm{P})$ and potassium $(\mathrm{K})$ contents in grains, roots and stem. According to the correlation between the vegetative traits and grain yield $\mathrm{kg} \mathrm{ha}^{-1}$ varied from 0.95 for no. of leaves plant ${ }^{-1}$ to 0.99 for chlorophyll content, fresh weight plant ${ }^{-1}$ as well as leaf area. Also, the simple correlation among agronomic and chemical traits had significant and positive relations with the grain yield $\mathrm{kg} \mathrm{ha}^{-1}$ under the investigated $\mathrm{N}$ treatments with an exception of $\mathrm{P}$ content that recorded a relatively high negative correlation with grain yield $\mathrm{ha}^{-1}(-0.589)$. It may be concluded from obtained results that dry weight as a vegetative trait, grain yield plant ${ }^{-1}$ as an agronomic trait and the ash as a chemical trait should be taking in considerations suggesting the importance of direct selection for these traits as important ones with grain yield $\mathrm{ha}^{-1}$ under studied treatments.
\end{abstract}

Keywords: quinoa, fertilizer, protein, NUE, direct effect.

\section{Introduction}

Soil fertility plays an important and major role in determining the growth and production capacity of any growing plant, either cultivated or wild (Mengel and Kirby 2001; Havlin et al., 2005). The balance of nutrient supply and uptake by a growing plant is one of the most important factors that improves the ability of plant to perform its physiological functions during its various development stages (Mengel and Kirby 2001; Havlin et al., 2005). In recent years, the attention in planting of Pseudocereal crops is increasing for their nutritional value. Among these crops are buckwheat, amaranths and quinoa that give from 2.3 to 3.4 ton/ha (Aufhammer et al., 1995). $\mathrm{N}$ fertilization improves the productivity of cereals. However, the optimum dosages for many crops have not yet been identified. Optimal fertilization is intended to save nutrient requirements by growing plants during their various growth stages. Although, some studies have been conducted to identify $\mathrm{N}$ requirements by quinoa plant, there is still a need for further detailed studies on the relationship of quinoa plant with $\mathrm{N}$ fertilization under saline and dry conditions. In general, there are limited studies to assess the efficiency of $\mathrm{N}$ fertilizer use, especially by developing plants under such environmental conditions, where these efficiencies can be improved by selecting high-capacity models for the use of applied N. The NUE by some crops has been estimated; for example, wheat yield (Dhugga and Waines, 1982) and barley yield (Tillman et al., 1991). Meyers (1998) studied the response of amaranth plant (Amaranthus spp.) under five levels of nitrogen fertilizer and found that biological and grain yields gradually increased with increasing $\mathrm{N}$ levels up to the highest level of $\mathrm{N}$ applied. Risi and Galwey 1994 and Schulte et al. (2005) evaluated the response of the quinoa yield to N fertilization rates and NUE and found that there is a strong response of the grain yield to $\mathrm{N}$ fertilization treatments. In addition, grain yields of quinoa proved

Corresponding Author: Ayman E. Badran, Department of Genetic Resources, Desert Research Center, Cairo, Egypt. E-mail: dr.ayman_badran@yahoo.com 
to increase significantly with increasing $\mathrm{N}$ fertilizations from 40 to $160 \mathrm{~kg} \mathrm{~N}^{-1}$ (Jacobsen et al., 1994). Additionally, the NUE did not show a reduction by increasing $\mathrm{N}$ fertilization (Erley et al., 2005).

However, such studies are not yet available for quinoa plant under the environmental stresses of dry and saline conditions. Correlation estimated the mutual association between two factors, which aid in determining the most effective characters for selection of high yield especially under different levels of stresses. However, correlation analysis is not enough to give an exact picture of relative importance of direct and indirect influence of each component characters on seed yield. Path coefficient analysis is an important tool for plant breeders, which helps in partitioning the correlation coefficient into components of direct and indirect influences and provides better insight on character and their relationship with yield (Badran et al., 2015).

Therefore, the aim of this experiment is to evaluate quinoa yield response to $\mathrm{N}$ fertilization, NUE as well as to estimate the path coefficient to determine the important traits that are directly or indirectly involved in determining the productivity of quinoa crop.

\section{Materials and Methods}

\section{Experimental conditions}

This experiment was carried out during both 2016 and 2017 winter seasons in the Agricultural and Veterinary Training and Research Station of King Faisal University (KFU), Al-Hassa, Kingdom of Saudi Arabia. The seeds of C. quinoa Willd. (Chipaya cv.) were obtained from the Desert Research Center, Cairo, Egypt. The experiment consisted of three treatments of $\mathrm{N}$ fertilizer (i.e., 0,80 and 160 $\mathrm{kg}$ of $\left.\mathrm{ha}^{-1}\right)$. The experimental design was a randomized complete block design with four replicates. The experimental area was divided into plots with each plot contains 10 rows of 4 meters length each. The cultivation was done with a density of 30 plants per square meter.

Before commencing the experiment, representative soil and irrigation water samples were collected. The soil samples were collected from the field surface layer (i.e., 0-30 cm). Their main soil physical, chemical and fertility properties were determined. The irrigation water samples were directly collected from the water source and analyzed for their main chemical properties. The analyses were done in the laboratories of the Department of Agricultural Environment and Natural Resources, College of Agricultural and Food Sciences, KFU, following recommended analytical methods (Chapman and Pratt, 1982; Page et al., 1982; Klute, 1986; Allen, 1989). The soil results (Tables 1a) indicated that the soil was sandy silt textured with an electrical conductivity (EC) of $2.02 \mathrm{dS} \mathrm{m}^{-1}$, a pH of 7.82 and low contents of organic matter and nutrients. The irrigation water results (Table 1b) showed that the main water characteristics were an EC of $1.95 \mathrm{~d} \mathrm{~S} \mathrm{~m}^{-1}$, a sodium absorption ratio (SAR) of 7.39 and a $\mathrm{pH}$ of 7.12 .

Table 1a: The results of the analysis of soil samples collected before planting.

\begin{tabular}{|c|c|c|c|c|c|c|c|}
\hline \multicolumn{2}{|c|}{ Physical properties } & \multicolumn{6}{|c|}{ Chemical and fertility properties } \\
\hline Item & Value (\%) & Item & Unit & Value & Item & Unit & Value \\
\hline Fine sand & $45.2 \%$ & EC & $\mathrm{dS} \mathrm{m}{ }^{-1}$ & 2.02 & pH & - & 7.2 \\
\hline Coarse sand & $35.4 \%$ & $\mathbf{N a}^{+}$ & & 5.24 & $\mathrm{CO}_{3}{ }^{-}$ & & \\
\hline Silt & $15.2 \%$ & $\mathbf{K}^{+}$ & $\mathrm{mmol}^{-1}$ & 5.87 & $\mathrm{HCO}_{3}^{-}$ & $\mathrm{mmol}^{-1}$ & 1.57 \\
\hline Clay & $4.2 \%$ & $\mathrm{Ca}^{2+}$ & mmor L & 2.15 & $\mathrm{Cl}^{-}$ & mmor L & 6.32 \\
\hline Textural Class & Sandy silt & $\mathbf{M g}^{2+}$ & & 0.65 & $\mathrm{SO}_{4}{ }^{2-}$ & & 6.71 \\
\hline Saturation & $18.2 \%$ & Organic & $\%$ & 1.2 & Extractable K & $\mathrm{mg} \mathrm{kg}^{-1}$ & 4.5 \\
\hline Available water & $9.0 \%$ & Total N & $\mathrm{mg} \mathrm{kg}^{-1}$ & 42.4 & Extractable $\mathbf{P}$ & $\mathrm{mg} \mathrm{kg}^{-1}$ & 200 \\
\hline
\end{tabular}

The nitrogen fertilizer in the urea form $(49 \% \mathrm{~N})$ was used in the experiment. It was applied in three rates (i.e., 0,80 and $160 \mathrm{~kg}$ of ha ${ }^{-1}$ ), representing the three $\mathrm{N}$ fertilizer treatments. The $\mathrm{N}$ in second treatment was applied in two equal doses. The first dose was applied after 20 days of planting and the second dose was after 20 days of the first one. While, the $\mathrm{N}$ in the third treatment was also applied in three equal doses that were sequentially added after 20, 40 and 60 days from the date of planting. In addition, both $\mathrm{P}$ (i.e., superphosphate, $48 \% \mathrm{P}_{2} \mathrm{O}_{5}$ ) and $\mathrm{K}$ (i.e., potassium sulphate, $15 \% \mathrm{~K}_{2} \mathrm{O}$ ) fertilizers were also applied in one dose each during the soil preparation for cultivation. The $\mathrm{P}$ fertilizer was 
applied at a rate of $75 \mathrm{~kg} \mathrm{ha}^{-1}$, whilst the $\mathrm{K}$ fertilizer was added at a rate of $50 \mathrm{~kg} \mathrm{ha}^{-1}$. During the experiment, all farming practices were performed according to recommended processes.

Table 1b: The results of irrigation water analysis.

\begin{tabular}{|c|c|c|c|c|c|c|c|c|c|c|c|}
\hline \multirow[t]{2}{*}{ Item } & \multirow[t]{2}{*}{ EC } & \multicolumn{8}{|c|}{ Soluble ions } & \multirow{2}{*}{ SAR } & \multirow{2}{*}{ pH } \\
\hline & & $\mathbf{N a}^{+}$ & $\mathbf{K}^{+}$ & $\mathrm{Ca}^{2+}$ & $\mathbf{M g}^{2+}$ & $\mathrm{CO}_{3}{ }^{-}$ & $\mathrm{HCO}_{3}^{-}$ & $\mathrm{Cl}^{-}$ & $\mathrm{SO}_{4}{ }^{2-}$ & & \\
\hline Unit & $\mathbf{d S} \mathbf{m}^{-1}$ & \multicolumn{8}{|c|}{$\operatorname{meq} L^{-1}$} & - & - \\
\hline Value & 1.95 & 7.27 & 5.43 & 2.86 & 1.01 & - & 2.68 & 8.40 & 2.02 & 7.39 & 6.96 \\
\hline
\end{tabular}

\section{Characters studied}

Various characters of growth, yield and its components as well as plant nutrient contents were recorded. These were done as follows:

\section{Measurements of yield and its components}

The samples of quinoa plants (Chipaya cv.) were taken after 30 days of planting. Each sample consisted of 10 plants that were removed randomly from the inner lines of the plot to measure the plant height $(\mathrm{cm})$, leaf area $\left(\mathrm{cm}^{2}\right)$, stem diameter $(, \mathrm{cm})$, fresh and dry weight per plant $(\mathrm{g})$, number of leaves per plant, chlorophyll content (SPAD). At harvest, the yield of grains per plant $\left(\mathrm{gm}^{-1}\right)$, grain yield $(\mathrm{kg}$ $\left.\mathrm{ha}^{-1}\right)$, weight of 1000 grains $(\mathrm{g})$, and number of grains per plant were estimated. Nitrogen fertilizer use efficiency (NUE) was calculated according to the following equation: NUE = Grain yield in $\mathrm{kg} \mathrm{ha}^{-1}$ / amount of mineral $\mathrm{N}$ added.

\section{Determination of nitrogen, phosphorus and potassium}

Samples of different parts of quinoa plant were collected, milled and digested according to Novozamsky et al., (1983) and analyzed for the followings: Plant N, P and K contents (g / kg) were determined according to Cottenie et al., 1982. A spectrophotometer at a $430 \mathrm{~nm}$ wavelength was used to estimate $\mathrm{P}$ content; while $\mathrm{K}$ was estimated using a flame photometer.

\section{Determination of total protein, fat, starch and fiber content in grain flour}

Total N was estimated using the Kjeldahl method as described by Pearson (1976). Then, protein ratio is calculated using the following equation: Protein $(\%)=\mathrm{N} \% \mathrm{X} 6.25$.

The fat was estimated by the Soxhlet extraction method as described in ICC Standard No. 136. The starch contents in seeds were determined by the polarimetrical method using $\mathrm{HCl}$ following the ICC Standard No. 123/1. The ash was also estimated as evidence of the total seeds content by the method of Standard No. 104/1. All these standard methods are in accordance to those listed in ICC Standards (1999).

\section{Statistical Analysis}

Data analysis of variance was conducted by $F$-test and means separation were obtained using the least significant difference test at 0.05 probability level $\left(\mathrm{LSD}_{0.05}\right)$ according to Gomez and Gomez (1984). Correlation coefficient were done following Singh and Chaudhary (1995).

\section{Results}

It is worth first to mention that the analysis of obtained results has confirmed the homogeneity between the growing two seasons of the studied traits. Accordingly, data presented here are an average of both seasons.

\section{Effect of nitrogen fertilization on some vegetative characters of quinoa}

The demand for $\mathrm{N}$ fertilizer application is increasing because of its effect on the growth of growing crops. The results in Table 2 indicate that there were significant effects of $\mathrm{N}$ fertilization rates on plant height, leaf area, stem diameter, fresh and dry weight /plant, numbers of leaves / plant and chlorophyll content. The details of these results are as such: 


\section{Plant height (cm):}

The results showed that the average of the plant height ranged from $25.15 \mathrm{~cm}$ of the control treatment $\left(0 \mathrm{~kg} \mathrm{~N} \mathrm{ha}^{-1}\right)$ to $75.9 \mathrm{~cm}$ for plants with the highest $\mathrm{N}$ application treatment $\left(160 \mathrm{~kg} \mathrm{~N} \mathrm{ha}^{-1}\right)$.

\section{Leaf area $\left(\mathrm{cm}^{-2}\right)$ :}

The results in Table 2 indicated that there were significant differences in the average of leaf area due to $\mathrm{N}$ fertilization treatments. Also, the results showed that the leaf area gradually increased with increasing rates of $\mathrm{N}$ fertilization. The area of leaf ranged from $10.47 \mathrm{~cm}^{2}$ at zero $\mathrm{kg} \mathrm{N} \mathrm{ha}{ }^{-1}$ (control) to $22.12 \mathrm{~cm}^{2}$ at $160 \mathrm{~kg} \mathrm{~N} \mathrm{ha}^{-1}$.

\section{Stem diameter $(\mathrm{cm})$ :}

The results of stem diameter trait showed that there was a significant response to $\mathrm{N}$ fertilization treatments, with recorded mean values were $0.45,0.95$ and $2.02 \mathrm{~cm}$ at $\mathrm{N}$ fertilization levels of zero, 80 and $160 \mathrm{~kg} \mathrm{~N} \mathrm{ha}^{-1}$, respectively (Table 2).

\section{Fresh and dry weights per plant (g):}

Both the fresh and dry weights of the plant significantly increased gradually with the addition of $\mathrm{N}$ fertilizers from zero to $160 \mathrm{~kg} \mathrm{~N}^{-1}$ (Table 2). Fresh weight averages were $12.14 \mathrm{~g}, 43.12 \mathrm{~g}$ and $66.56 \mathrm{~g}$ for plants receiving 0,80 and $160 \mathrm{~kg} \mathrm{~N} \mathrm{ha}^{-1}$, respectively. Also, the plant dry weight values were in consistent with those of plant fresh weight values. The plant dry weight values were $1.52,6.53$ and $18.11 \mathrm{~g}$ / plant for $\mathrm{N}$ fertilization levels, respectively.

\section{Number of leaves per plant:}

The results in Table 2 showed that $\mathrm{N}$ fertilization rates significantly improved number of leaves / plant. The values of number of leaves / plant were 20,25 and 43 for plants receiving 0,80 and $160 \mathrm{~kg}$ $\mathrm{N}$ ha ${ }^{-1}$ fertilizer, respectively.

\section{Chlorophyll content (SPAD):}

The results in Table 2 showed a significant increase in the chlorophyll content under the influence of $\mathrm{N}$ fertilization. The ratio of chlorophyll was 32.1 with control treatment ( $0 \mathrm{~N}$ fertilizer), 48.10 at the addition of $80 \mathrm{~kg} \mathrm{~N} \mathrm{ha}^{-1}$ and 70.28 when plants fertilized with the highest $\mathrm{N}$ fertilizer rate $\left(160 \mathrm{~kg} \mathrm{~N} \mathrm{ha}^{-}\right.$ $\left.{ }^{1}\right)$.

Table 2: Mean performance of agronomic characters of quinoa plant under different $\mathrm{N}$ treatments.

\begin{tabular}{lccccccc}
\hline $\begin{array}{l}\text { N treatments } \\
\left(\mathbf{k g ~ N ~ h a} \mathbf{-}^{-1}\right)\end{array}$ & $\begin{array}{c}\text { Plant } \\
\text { height } \\
(\mathbf{c m})\end{array}$ & $\begin{array}{c}\text { Leaf area } \\
\left(\mathbf{c m}^{2}\right)\end{array}$ & $\begin{array}{c}\text { Stem } \\
\text { diameter } \\
\mathbf{( c m )}\end{array}$ & $\begin{array}{c}\text { Fresh } \\
\text { weight / } \\
\text { plant (g) }\end{array}$ & $\begin{array}{c}\text { Dry } \\
\text { weight / } \\
\text { plant (g) }\end{array}$ & $\begin{array}{c}\text { No. of } \\
\text { leaves / } \\
\text { plant }\end{array}$ & $\begin{array}{c}\text { Chlorophyll } \\
\text { content } \\
\text { (SPAD) }\end{array}$ \\
\hline $\mathbf{0}$ & 25.15 & 10.47 & 0.45 & 12.14 & 1.52 & 20 & 32.10 \\
$\mathbf{8 0}$ & 40.31 & 15.74 & 0.95 & 43.12 & 6.53 & 25 & 48.10 \\
$\mathbf{1 6 0}$ & 75.90 & 22.12 & 2.02 & 66.56 & 18.11 & 43 & 70.28 \\
LSD $_{0.05}$ & 2.821 & 3.77 & 1.47 & 4.57 & 2.88 & 4.29 & 4.35 \\
\hline
\end{tabular}

Means in the same column followed by the same letters are insignificantly different at a 0.05 probability level.

\section{Effect of $\mathbf{N}$ fertilization on some agronomic characters and nitrogen fertilizer use efficiency (NUE) of quinoa}

The obtained results showed various effects on the agronomic characteristics (i.e., weight of grain yield / plant, number of grains / plant, weight of 1000 grains and grain yield per hectare) of grown quinoa plants and their NUE (Table 3). These variations are as follows:

\section{Weight of grain yield per plant (g):}

The results recorded in Table 3 indicate that there was a significant increase $(P<0.05)$ in the weight of grains / plant as influenced by the application of $\mathrm{N}$ fertilizer levels. The values of grain yield 
ranged between $2.481 \mathrm{~g} /$ plant for the control treatment and $18.080 \mathrm{~g} / \mathrm{plant}$ for the highest $\mathrm{N}$ fertilizer application.

\section{Number of grains per plant:}

The number of grains / plant increased significantly with the increasing rates of $\mathrm{N}$ fertilizer application (Table 3). Their values were 2418, 3436.5 and 5207.3 grains / plant for the 0,80 and 160 $\mathrm{kg} \mathrm{N} \mathrm{ha}^{-1}$ treatments, respectively.

\section{The weight of 1000 grain (g):}

The results in Table 3 showed that there were vital impacts of $\mathrm{N}$ fertilization rates on the weight of 1000 grains that gradual increased from 1.026, 2.545 and $3.472 \mathrm{~g} / 1000$ grains for the $\mathrm{N}$ fertilization

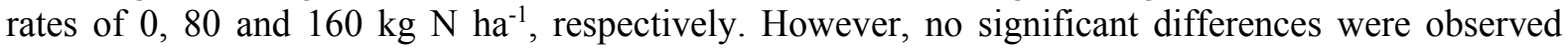
between the values obtained under the latter $\mathrm{N}$ fertilization treatments.

\section{Nitrogen use efficiency (NUE):}

The values were significantly decreased with increasing $\mathrm{N}$ fertilizer applications. Their values varied between 5.52 and 4.31 under the 80 and $160 \mathrm{~kg} \mathrm{~N} \mathrm{ha}^{-1}$ application rates, respectively (Table 3).

\section{Grain yield per hectare $\left(\mathrm{kg} \mathrm{ha}^{-1}\right)$ :}

It may be seen from Table 3 that the grain yield per hectare significantly increased with increasing $\mathrm{N}$ fertilizer application rates. Their values were $101.23,430.70$ and $770.20 \mathrm{~kg} \mathrm{ha}^{-1}$ for 0,80 and $160 \mathrm{~kg}$ $\mathrm{N} \mathrm{ha}^{-1}$, respectively. These increases in grain yields were estimated to be $325.47 \%$ and $759.62 \%$ for the 80 and $160 \mathrm{~kg} \mathrm{~N}^{-1} \mathrm{~kg} \mathrm{~N}^{-1}$ treatments as compared with control.

Table 3: Effect of $\mathrm{N}$ fertilizer treatments on nitrogen fertilizer use efficiency and grain yield and its components.

\begin{tabular}{cccccc}
\hline $\begin{array}{c}\text { N Treatment } \\
\left(\mathbf{k g ~ N ~ h a ~}^{-\mathbf{1}}\right)\end{array}$ & $\begin{array}{c}\text { Grain yield / } \\
\text { plant (g) }\end{array}$ & $\begin{array}{c}\text { No. of grains } \\
\text { / plant }\end{array}$ & $\begin{array}{c}\text { weight of 1000 } \\
\text { grains (g) }\end{array}$ & $\begin{array}{c}\text { Grain yield } \\
\left.\mathbf{k g ~ h a}^{-1}\right)\end{array}$ & NUE $^{*}$ \\
\hline $\mathbf{0}$ & 2.481 & 2418.0 & 1.026 & 101.23 & 0.00 \\
$\mathbf{8 0}$ & 8.746 & 3436.5 & 2.545 & 430.70 & 5.52 \\
$\mathbf{1 6 0}$ & 18.080 & 5207.3 & 3.472 & 770.20 & 4.31 \\
$\mathbf{L S D}_{(\mathbf{0 . 0 5}}$ & 2.071 & 8.782 & 1.333 & 5.174 & 1.398 \\
\hline
\end{tabular}

Means in the same column followed by the same letters are insignificantly different at a 0.05 probability level,

* NUE $=$ nitrogen use efficiency.

\section{Effect of $\mathbf{N}$ fertilization on some chemical characters of quinoa}

The results of this study revealed that there were diverse effects of $\mathrm{N}$ fertilizer levels on the chemical characters of quinoa plants as presented in their contents of N, P and $\mathrm{K}$ (Table 4) and protein, starch, fat and fiber (Table 5). These results are as followings:

\section{Nitrogen, phosphorus and potassium contents:}

It could be seen from Table 4 that there were significant differences in the values of $\mathrm{N}, \mathrm{P}$ and $\mathrm{K}$ contents in the seed, stem and root of the quinoa under the applied rates of $\mathrm{N}$ fertilizer $(0,80$ and 160 $\left.\mathrm{kg} \mathrm{N} \mathrm{ha}{ }^{-1}\right)$. An exception was observed where the root $\mathrm{K}$ content was not significantly affected by these different $\mathrm{N}$ fertilizer treatments.

Table 4: Effects of $\mathrm{N}$ fertilizer treatments on the N, P and K contents of the different parts of quinoa plant.

\begin{tabular}{|c|c|c|c|c|c|c|c|c|c|}
\hline \multirow{4}{*}{$\begin{array}{l}\text { N Treatments } \\
\left(\mathrm{kg} \mathrm{N} \mathrm{ha}^{-1)}\right.\end{array}$} & \multicolumn{9}{|c|}{ Plant Parts } \\
\hline & \multicolumn{3}{|c|}{ Grain } & \multicolumn{3}{|c|}{ Stem } & \multicolumn{3}{|c|}{ Root } \\
\hline & $\mathbf{N}$ & $\mathbf{P}$ & $\mathbf{K}$ & $\mathbf{N}$ & $\mathbf{P}$ & $\mathbf{K}$ & $\mathbf{N}$ & $\mathbf{P}$ & $\mathbf{K}$ \\
\hline & \multicolumn{9}{|c|}{ (\%) } \\
\hline 0 & 2.37 & 0.09 & 1.37 & 0.652 & 0.010 & 1.48 & 0.728 & 0.023 & 1.367 \\
\hline 80 & 2.50 & 0.10 & 1.48 & 0.810 & 0.027 & 2.06 & 0.767 & 0.042 & 1.487 \\
\hline 160 & 2.74 & 0.42 & 1.66 & 0.942 & 0.050 & 3.33 & 0.925 & 0.085 & 1.560 \\
\hline $\operatorname{LSD}_{(0.05)}$ & 0.37 & 0.025 & 0.210 & 0.126 & 0.009 & 0.307 & 0.142 & 0.009 & 0.220 \\
\hline
\end{tabular}

Note: Means in the same column followed by the same letters are insignificantly different at a 0.05 probability level. 
Generally, the $\mathrm{N}$ and $\mathrm{P}$ contents in the studied quinoa parts showed an increasing trend with the increased applied rates of $\mathrm{N}$ fertilizer. In details, the values of $\mathrm{N}, \mathrm{P}$ and $\mathrm{K}$ in the grains ranged from 2.37 to $2.74,0.09$ to 0.42 and 1.37 to $1.66 \%$, respectively. The ranges of $\mathrm{N}, \mathrm{P}$ and $\mathrm{K}$ in the stem were respectively from 0.652 to $0.942,0.010$ to 0.050 and 1.48 to $3.33 \%$. The values of these elements in the roots varied from 0.728 to 0.925 and 0.023 to 0.085 , respectively. The results also showed that the average ratios of these elements were in order of $\mathrm{N}>\mathrm{K}>\mathrm{P}$. Furthermore, the mean $\mathrm{N}$ ratios in grain $(2.54)>\operatorname{stem}(0.801) \leq \operatorname{root}(0.807)$, while the mean $\mathrm{P}$ ratios in grain $(0.202)>\operatorname{root}(0.050)>$ stem (0.029), and the mean ratios of $\mathrm{K}$ in stem (2.283) $>$ grain $(1.503)>\operatorname{root}(1.471)$.

\section{Total protein, starch, fat and fiber contents}

Results in Table 5 shows that the $\mathrm{N}$ fertilizer treatments $\left(0,80\right.$ and $\left.160 \mathrm{~kg} \mathrm{~N}^{-1}\right)$ caused significant differences in the values of total protein contents in the dry grain flour of quinoa plant. These values of protein were $14.81 \%, 15.63 \%$ and $17.13 \%$, respectively. However, there were no significant differences at the 0.05 probability level between the control and $80 \mathrm{~kg} \mathrm{~N} \mathrm{ha}^{-1}$ treatments neither between the latter and $160 \mathrm{~kg} \mathrm{~N} \mathrm{ha}^{-1}$ treatments. This implies that the protein content of in the dry grain flour of quinoa plant increases with the increasing applied rates of $\mathrm{N}$ fertilizer.

Likewise, the results of the starch content in the dry grain flour of quinoa plant indicated that there were significant differences between the $\mathrm{N}$ fertilizer treatments (Table 5). There were gradual increases in the starch values with increasing $\mathrm{N}$ fertilizer applications from zero to $160 \mathrm{~kg} \mathrm{~N}^{-1}$. However, the results showed that no significant differences in the starch grain contents between the $\mathrm{N}$ fertilizer treatments of 0 and $80 \mathrm{~kg} \mathrm{~N} \mathrm{ha}^{-1}$. The starch values ranged between 43.20 and $55.87 \%$ of the dry weight of the grain flour. Similarly, there were significant differences in the fat content of the dry quinoa grain flour between the $\mathrm{N}$ fertilizer treatments. The results showed that there were steady increases in the findings of the fat content with increased $\mathrm{N}$ fertilizer applications from zero to $160 \mathrm{~kg} \mathrm{~N} \mathrm{ha}^{-1}$. The fat content values were respectively $2.99,4.32$ and $6.64 \%$ for the $\mathrm{N}$ fertilizer treatments.

Ash estimation in plant components is a vital indicator of plant mineral contents. Table 5 shows the response of quinoa plant to $\mathrm{N}$ fertilizer treatments as indicated by grain ash contents that showed significant differences in their values of to the $\mathrm{N}$ fertilization. Results also exhibited a significant increase with increasing $\mathrm{N}$ fertilization. Ash values ranged from $1.52 \%$ to $6.14 \%$ at the zero and $160 \mathrm{~kg}$ $\mathrm{N} \mathrm{ha}^{-1}$ treatments, respectively. This trend of these values is in harmony with the values of the protein and elements in the quinoa grain.

Table 5: Effects of $\mathrm{N}$ fertilizer treatments on protein, fat, starch and ash in dry grain flour of quinoa plants.

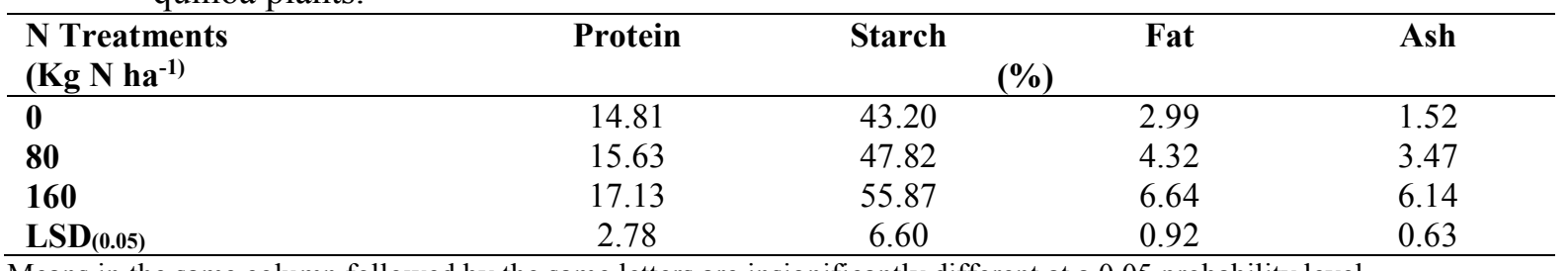

Means in the same column followed by the same letters are insignificantly different at a 0.05 probability level.

\section{Correlation coefficient analysis of all studied traits}

Correlation coefficient studies between tested traits and yield are vital tolls in plant breeding programs for indirect selection and have been of great values in evaluating the most effective breeding procedures. Obtained findings revealed that the correlation values between vegetative traits and grain yield ha ${ }^{-1}$ varied from 0.95 for no. of leaves plant ${ }^{-1}$ to 0.99 for chlorophyll content, fresh weight plant ${ }^{-1}$ as well as leaf area (Table 6). In addition, simple correlation coefficient among agronomic traits under the studied $\mathrm{N}$ fertilizer treatments were estimated (Table 6). Their results indicated that NUE (0.737), no. of grain plant ${ }^{-1}(0.989)$, weight of 1000 grains $(0.989)$ and grain yield/plant (0.995) had significant and positive relations with the grain yield ha ${ }^{-1}$ under the investigated $\mathrm{N}$ treatments. Moreover, the results of the correlation coefficients between all studied chemical traits and the grain yield/ha under $\mathrm{N}$ fertilizer treatments were showed strong positive significances among them (Table 6). Their values differed between 0.987 and 0.997 , with an exception of $\mathrm{P}$ content that recorded a relatively high negative correlation with grain yield ha-1 $(-0.589)$. 
Table 6: Simple correlation coefficients among the vegetative, agronomic, chemical traits and grain yield / ha under the $\mathrm{N}$ fertilizer treatments.

\begin{tabular}{|c|c|c|c|c|c|}
\hline Vegetative traits & $\begin{array}{c}\text { Grain yield } \\
\mathrm{ha}^{-1}\end{array}$ & Agronomic traits & $\begin{array}{c}\text { Grain } \\
\text { yield } \\
\text { ha }^{-1} \\
\end{array}$ & $\begin{array}{l}\text { Chemical } \\
\text { traits }\end{array}$ & $\begin{array}{c}\text { Grain yield } \\
\text { ha }^{-1}\end{array}$ \\
\hline Chlorophyll content & $0.99^{*}$ & $\mathrm{~N}$ use efficiency & $0.737^{*}$ & $\mathbf{N}$ & $0.987 *$ \\
\hline No. of leaves plant ${ }^{-1}$ & $0.95^{*}$ & No. of grains plant ${ }^{-1}$ & $0.989 *$ & $\mathbf{P}$ & $-0.589 *$ \\
\hline Dry wt. plant ${ }^{-1}$ & $0.97 *$ & Wt. of 1000 & $0.989^{*}$ & $\mathbf{K}$ & $0.999 *$ \\
\hline Fresh wt. plant ${ }^{-1}$ & $0.99 *$ & Grain yield plant $^{-1}$ & $0.995 *$ & Protein & $0.987 *$ \\
\hline Stem diameter & $0.98^{*}$ & & & Starch & $0.989 *$ \\
\hline Leaf area & $0.99 *$ & & & Fat & $0.989 *$ \\
\hline Plant height & $0.97 *$ & & & Ash & $0.997 *$ \\
\hline
\end{tabular}

${ }^{*}$ Refers to significant differences at a 0.05 probability level.

Table 7: Simple correlation coefficient among agronomic traits under $\mathrm{N}$ fertilizer treatments.

\begin{tabular}{l|cccc}
\hline Traits & N use efficiency & $\begin{array}{c}\text { No. of grains } \\
\text { plant }^{-1}\end{array}$ & $\begin{array}{c}\text { weight of 1000 } \\
\text { grains }\end{array}$ & $\begin{array}{c}\text { Grain yield }^{\text {plant }} \\
\text { plin }^{-1}\end{array}$ \\
\hline No. of grains plant & & & & \\
Wt. of 1000 & $0.631^{*}$ & $0.957^{*}$ & & \\
Grain yield plant $^{-1}$ & $0.828^{*}$ & $0.699^{*}$ & $0.968^{*}$ & \\
Grain yield ha $^{-1}$ & $0.662^{*}$ & $0.989^{*}$ & $0.989^{*}$ & $0.995^{*}$ \\
\hline
\end{tabular}

${ }^{*}$ Refers to significant differences at a 0.05 probability level.

Table 8: Correlation coefficient between chemical traits and grain yield / ha under the $\mathrm{N}$ fertilizer treatments.

\begin{tabular}{l|ccccccc}
\hline Trait & N & P & K & Protein & Starch & Fat & Ash \\
\hline P & $-0.452^{*}$ & & & & & & \\
K & $0.986^{*}$ & $-0.596^{*}$ & & & & & \\
Protein & $0.999^{*}$ & $-0.454^{*}$ & $0.986^{*}$ & & & & \\
Starch & $0.999^{*}$ & $-0.465^{*}$ & $0.988^{*}$ & $0.999^{*}$ & & & \\
Fat & $0.999^{*}$ & $-0.465^{*}$ & $0.988^{*}$ & $0.999^{*}$ & $0.998^{*}$ & & \\
Ash & $0.997^{*}$ & $-0.522^{*}$ & $0.996^{*}$ & $0.997^{*}$ & $0.998^{*}$ & $0.998^{*}$ & \\
Grain yield ha-1 & $0.987^{*}$ & $-0.589^{*}$ & $0.999^{*}$ & $0.987^{*}$ & $0.989^{*}$ & $0.989^{*}$ & $0.997^{*}$ \\
\hline
\end{tabular}

${ }^{*}$ Refers to significant differences at a 0.05 probability level.

In addition, path coefficient analysis was used as a statistical technique to partition the correlation coefficient into its direct and indirect effects in order to estimate the contribution of each trait to grain yield of quinoa plant (Table 9). Thus, the values listed in Table 9 imply that the correlation coefficients between chlorophyll content, no. of leaves/plant, dry and fresh weights, stem diameter, leaf area and plant height traits and grain yield (i.e., 0.99, 0.95, 0.97, 0.99, 0.98, 0.99 and 0.97, respectively).

Table 9: Partition the correlation coefficient into direct and indirect effects for the mean of vegetative traits and grain yield ha ${ }^{-1}$ of quinoa plant under the $\mathrm{N}$ fertilizer treatments.

\begin{tabular}{|c|c|c|c|c|c|c|c|c|c|}
\hline \multirow[t]{2}{*}{ Traits } & \multirow{2}{*}{$\begin{array}{l}\text { Direct } \\
\text { effect }\end{array}$} & \multicolumn{7}{|c|}{ Indirect effect } & \multirow{2}{*}{$\begin{array}{c}\text { Correl. } \\
\text { with grain } \\
\text { yield ha }{ }^{-1}\end{array}$} \\
\hline & & $\mathrm{CC}^{1}$ & $\mathbf{N L P}^{2}$ & DWtP ${ }^{3}$ & FWtP $^{4}$ & SD $^{5}$ & $\mathbf{L A}^{6}$ & $\mathbf{P H}^{7}$ & \\
\hline Chlorophyll content & 0.78 & - & -1.716 & 3.710 & 1.239 & -0.026 & -2.749 & -0.248 & 0.99 \\
\hline No. of leaves plant ${ }^{-1}$ & -1.76 & 0.760 & - & 3.710 & 1.160 & -0.02 & -2.65 & -0.250 & 0.95 \\
\hline Dry wt. plant ${ }^{-1}$ & 3.75 & 0.770 & -1.759 & - & 1.190 & -0.02 & -2.71 & -0.251 & 0.97 \\
\hline Fresh wt. plant ${ }^{-1}$ & 1.258 & 0.760 & -1.621 & 3.570 & - & -0.026 & -2.721 & -0.230 & 0.99 \\
\hline Stem diameter & -0.027 & 0.773 & -1.73 & 3.730 & 1.205 & - & -2.72 & -0.250 & 0.98 \\
\hline Leaf area & -2.752 & 0.772 & -1.700 & 3.690 & 1.240 & -0.020 & - & -0.240 & 0.99 \\
\hline Plant height & -0.251 & 0.77 & -1.750 & 3.740 & 1.190 & -0.020 & -2.71 & - & 0.97 \\
\hline
\end{tabular}

(1) $\mathrm{CC}=$ chlorophyll content; (2) $\mathrm{NLP}=$ no. of leaves / plant; (3) DWtP=dry weight / plant; (4) $\mathrm{FWtP}=$ fresh weight / plant; (5) $\mathrm{SD}=$ stem diameter; (6) $\mathrm{LA}=$ leaf area \& (7) $\mathrm{PH}=$ plant height.

The direct effect of no. of grains / plant and the weight of 1000 grain were negative values of 2.120 and -0.150 , respectively (Table 10). Both NUE and grain yield /plant recorded positive values 
(0.075 and 3.280, respectively) (Table 10). In the same manner, the direct effects for both ash and $\mathrm{N}$ with grain yield/ha were positive and considerable (i.e., 0.742 and 0.515 , respectively), whilst the value was positive but limited for $\mathrm{K}(0.088)$ (Table 11$)$. However, the values of direct effects for P, protein, starch and fat were negative and virtually negligible (i.e., $-0.099,-0.314,-0.048$ and -0.035 ) (Table 11).

Table 10: Partition of the correlation coefficients into direct and indirect effects for the mean of agronomic traits and grain yield $\mathrm{ha}^{-1}$ of quinoa plant under the $\mathrm{N}$ fertilizer treatments.

\begin{tabular}{|c|c|c|c|c|c|c|}
\hline \multirow[t]{2}{*}{ Trait } & \multirow{2}{*}{$\begin{array}{l}\text { Direct } \\
\text { effect }\end{array}$} & \multicolumn{4}{|c|}{ Indirect effect } & \multirow{2}{*}{$\begin{array}{l}\text { Correl. with } \\
\text { grain yield ha- }\end{array}$} \\
\hline & & $\mathrm{NUE}^{1}$ & NGP $^{2}$ & $\mathrm{Wt1000}^{3}$ & GYP $^{4}$ & \\
\hline NUE & 0.075 & 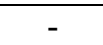 & -1.337 & -0.124 & 2.124 & 0.737 \\
\hline No. of grains plant ${ }^{-1}$ & -2.120 & 0.047 & - & -0.144 & 3.205 & 0.989 \\
\hline Wt. of 1000 grain & -0.150 & 0.062 & -2.028 & - & 3.105 & 0.989 \\
\hline Grain yield plant ${ }^{-1}$ & 3.208 & 0.049 & -2.117 & -0.145 & - & 0.995 \\
\hline
\end{tabular}

(1) NUE=N use efficiency; (2) NGP=no. of grains / plant; (3) Wt1000= weight of 1000 grains \& (4) GYP=grain yield / plant.

Table 11: Partition of the correlation coefficients into direct and indirect effects for the mean of chemical traits and grain yield ha ${ }^{-1}$ of quinoa plant under the $\mathrm{N}$ fertilizer treatments.

\begin{tabular}{l|c|ccccccc|c}
\hline \multirow{2}{*}{ Traits } & Direct & \multicolumn{7}{|c|}{ Indirect effect } & Correl. with \\
\cline { 3 - 9 } & effect & $\mathbf{N}$ & $\mathbf{P}$ & $\mathbf{K}$ & Protein & Starch & Fat & Ash & grain yield ha $^{-1}$ \\
\hline $\mathbf{N}$ & 0.515 & - & 0.044 & 0.087 & -0.314 & -0.048 & -0.035 & 0.739 & 0.987 \\
$\mathbf{P}$ & -0.099 & -0.232 & - & -0.052 & 0.143 & 0.023 & 0.016 & -0.387 & -0.589 \\
$\mathbf{K}$ & 0.088 & 0.507 & 0.059 & - & -0.310 & -0.048 & -0.035 & 0.739 & 0.999 \\
Protein & -0.314 & 0.514 & 0.044 & 0.080 & - & -0.048 & -0.035 & 0.739 & 0.987 \\
Starch & -0.048 & 0.514 & 0.046 & 0.087 & -0.314 & - & -0.035 & 0.740 & 0.989 \\
Fat & -0.035 & 0.514 & 0.046 & 0.087 & -0.314 & -0.048 & - & 0.740 & 0.989 \\
Ash & 0.742 & 0.513 & 0.052 & 0.088 & -0.313 & -0.048 & -0.035 & - & 0.997 \\
\hline
\end{tabular}

\section{Discussion}

\section{Effect of $\mathbf{N}$ fertilizer on the vegetative and agronomic characters of quinoa plant}

The results of this investigation revealed that increasing $\mathrm{N}$ fertilizer applications significantly enhanced the studied vegetative and yield traits of quinoa plant. This might be due to the $\mathrm{N}$ crucial function in stimulating metabolic activities, accelerating metabolic products and hence improving growth leading to a better yield qualitatively as well as quantitatively. These results are in harmony with those reported by other investigators (Pospišil et al., 2006; Abou-Amer and Kamel, 2011; Guo et al., 2014; Geren, 2015; Leghari et al., 2016) who proposed that increasing $\mathrm{N}$ application enhances plant growth characters and improves yield and yield components of various plants.

Bhargava et al. (2008) in their study evaluating 12 quinoa genotypes in India and reported that the mean values of plant height $(83.76 \mathrm{~cm} \pm 6.79)$, leaf area $\left(18.15 \mathrm{~cm}^{-2} \pm 1.44\right)$, stem diameter $(0.86 \mathrm{~cm}$ $\pm 0.05)$, dry weight/plant $(16.37 \mathrm{gm} \pm 2.24)$, grain yield/plant $(16.27 \mathrm{gm} \pm 2.06)$, and 1000 seed weight (2.69 gm \pm .015 ). Geren (2015) concluded that applying $150 \mathrm{~kg} \mathrm{~N}^{-1}$ proved to be best level for $\mathrm{N}$ soil supply for grain yield of quinoa $\left(2.95 \mathrm{t} \mathrm{ha}^{-1}\right)$ and protein content $(16 \%)$ under the Mediterranean ecological conditions in Turkey. Likewise, in Pakistan Basra et al. (2014) found that soil application rates between 75 and $125 \mathrm{~kg} \mathrm{~N} \mathrm{ha}^{-1}$ improved chlorophyll content; with the $75 \mathrm{~kg} \mathrm{~N}^{-1}$ rate was bets level to achieve maximum economic yield values. Erley et al. (2005) emphasized that quinoa plant responded strongly to $\mathrm{N}$ fertilization, implying its grain yield increased by $194 \%$ at $120 \mathrm{~kg} \mathrm{~N} \mathrm{ha}^{-1}$ as compared to the zero $\mathrm{N}$ application (i.e., 3495 and $1790 \mathrm{~kg} \mathrm{ha}^{-1}$, respectively). Jacobsen et al. (1994) confirmed in a study on quinoa plant that its yield increased with increasing $\mathrm{N}$ fertilization rates from 40 to $160 \mathrm{~kg} \mathrm{~N} \mathrm{ha}^{-1}$ under moderate temperate conditions in Denmark.

Thus, these reported results of growth and yield traits of quinoa are in accordance with the data recorded in the current investigation (Tables 2 and 3). This infers the positive and significant of $\mathrm{N}$ fertilization effects on quinoa. Leghari et al. (2016) indicated that the $\mathrm{N}$ element as an essential macronutrient of plant growth and development consequently improves and augments the yield and its quality via its imperative roles in the biochemical and physiological functions in the growing plant. Lawlor (2002) proposed that supplying adequate $\mathrm{N}$ quantity at appropriate time for growing crops ascertains the patterns of their growth and production, which are consequence of the proteins as basis 
of metabolic processes with the light energy utilized in reductions of both $\mathrm{CO}_{2}$ and $\mathrm{NO}_{3}{ }^{-}$and synthesis of assimilates that are used in vegetative and reproductive growth and yield developments.

\section{Effect of $\mathbf{N}$ fertilization on nitrogen use efficiency of quinoa}

The results shown in Table 3 of this study indicated that there was an inverse relationship between $\mathrm{N}$ fertilization and NUE, with best value was at the rate of $80 \mathrm{~kg} \mathrm{~N}^{-1}$. However, there was no significant differences at $5 \%$ probability level between the application rates of 80 and $160 \mathrm{~kg} \mathrm{~N}$ ha${ }^{1}$ (i.e., 5.52 and $4.31 \mathrm{~kg}$ of grains ha ${ }^{-1} / \mathrm{kg}$ of $\mathrm{N} \mathrm{ha}^{-1}$, respectively). These results are consistent with the findings of other researchers who emphasized that increasing $\mathrm{N}$ application does not necessarily increase NUE (Meyers, 1998; Schulte et al., 2005; Pospišil et al., 2006; Abou-Amer and Kamel, 2011; Kakabouki et al., 2018). Many investigations have proposed that there are numerous environmental, agronomic and genetic factors that affect NUE (Benincasa et al., 2011; MacDonald et al., 2013; Caixeta et al., 2015; Stahl et al., 2017), which in summary is a function of plant potential to uptake or acquisition $\mathrm{N}$ from the soil and its ability to physiologically utilize the absorbed $\mathrm{N}$ (Pathak et al., 2011). Kakabouki et al. (2018) concluded that quinoa plants are highly competent in absorbing soil N; however, they appear poor in remobilizing $\mathrm{N}$ from the vegetative parts into the seeds under high $\mathrm{N}$ supply. This might therefore elucidate the quite low NUE achieved in the current study (Table 3).

\section{Effect of nitrogen fertilization on some chemical characters of quinoa}

It may be seen from this experiment that $\mathrm{N}$ fertilization had significant impacts on the chemical traits of studies quinoa under Al-Hassa environmental conditions. The N, P, and K contents of the plant parts generally increased with increasing $\mathrm{N}$ fertilizer application (Table 4). Total protein, starch, fat and ash were also significantly improved with increasing $\mathrm{N}$ fertilizer rates (Table 5). These results are in consistent with the findings presented in other studies (Jacobsen, et al., 1994; Sa-Nguansak, 2004; Erley et al., 2005; Bhargava et al., 2008; Abou-Amer and Kamel, 2011; Geren, 2015). Thus, it may be presumed from these results that quinoa plants grown under the conditions of Al-Hassa Oasis preserves substantial nutritional values compatible with those from other regions of the world (Poonia and Upadhayay, 2015; Navruz-Varli and Sanlier, 2016; Vilcacundo and Hernandez-Ledesma, 2017; Zikankuba and James, 2017).

\section{Simple correlation and path analysis}

Dewey and $\mathrm{Lu}$ (1959) suggested that the analysis of simple correlation coefficient to elucidate the relationship of grain yield to a single variable might not provide a complete understanding about the importance of each component in determining seed yield. Accordingly, the results in Table 9 emphasizes that the selection of both stem diameter and plant height (i.e., direct selection) would not be reliable criteria for improving grain yield, which should be done through dry weight (i.e., indirect selection). This trend is consistent with the suggestions of plant breeders (Yasin and Singh 2010), who prefer yield components that indirectly increase yield. Direct effect of grain yield/plant on grain yield/ha is greater than indirect effect of other traits indicating that direct selection of grain yield/plant may be reliable criteria for improving grain yield/ha. These results agree with those by Singh and Chaudhary (1995), who reported that if the correlation between a causal factor and the effect is almost equal to its direct, then correlation explains the true relationship and a direct selection through this trait well be effective. The results also indicate that both ash and nitrogen content traits must be considered as very important ones to improve yield. However, the results indicate that protein, starch and fat were negative so they may be used as limited reliable criteria for improving grain yield under conditions and used indirect effect selection through ash content for high grain yield of quinoa and these finding in harmony with Singh and Kakar (1977).

\section{Conclusion}

It may be concluded from this study that the yield of quinoa grains per hectare under the conditions of Al-Hassa Oasis, KSA was significantly increased with increasing $\mathrm{N}$ fertilization rates that also affected vegetative, chemical and agronomical traits. It could be also concluded that dry weight, as a vegetative trait; grain yield/plant, as an agronomic trait, and the ash, as a chemical trait, should be considered in plant selecting, suggesting the importance of direct selection for these traits as the important traits with grain yield/ha under tested treatments. 


\section{Acknowledgment}

Authors would like to greatly acknowledge the Deanship of Scientific Research at KFU for funding this project. They are also grateful to Desert Research Center, Cairo for providing the seeds. Many thanks are for Prof. M.M. El-Garawany for his technical supports and advices.

\section{References}

Abou-Amer, A.I. and A.S. Kamel, 2011. Growth, yield and nitrogen utilization efficiency of quinoa (Chenopodium quinoa) under different rates and methods of nitrogen fertilization.. Egypt J. Agron. 33(2): 155-166.

Allen, S.E., 1989. Chemical Analysis of Ecological Materials (second edition). Blackwell Scientific Publications, London, UK.

Aufhammer, W., J.H. Lee, E. Kubler, M. Kuhn and S. Wagner, 1995. Pseudocereal cultivation and suitability of buckwheat (Fagopyrum esculentum), quinoa (Chenopodium quinoa) and Amaranth (Amaranthus ssp.). Die Bodenkultur, 4: 125-140.

Badran A.E., M.R.A. AbdAlhady and W.A. Hassan, 2015. In Vitro Evaluation of Some Traits in Stevia rebaudiana (Bertoni) under Drought Stress and Their Relationship on Stevioside Content.American Journal of Plant Sciences 6: 746-752.

Basra, S.M.A., S. Iqbal and I. Afzal, 2014. Evaluating the response of nitrogen application on growth, development and yield of quinoa genotypes. International Journal of Agriculture \& Biology 16: 886-892.

Benincasa, P., M. Guiducci and F. Tei, 2011. The nitrogen use efficiency: Meaning and source of variation - case studies on three vegetable crops in Central Italy. HortTechnology 21(3): 266-273.

Bhargava, A., S. Shukla and D. Ohri, 2008. Implications of direct and indirect selection parameters for improvement of grain yield and quality components in Chenopodium quinoa Willd. International Journal of Plant Production 2(3): 183-191.

Caixeta, D.S., R. Fritsche-Neto, Í.S.C. Granato and L.R.O.J.C. Cardoso, 2015. Early indirect selection for nitrogen use efficiency in maize. Revista Ciência Agronômica 46(2): 369-378.

Chapman, H.D. and P.F. Pratt (1982). Methods of Analysis for Soils, Plants and Waters. Division of Agricultural Sciences, University of California, Berkeley, CA, USA.

Cottenie, A., M. Verloo, G. Velgh, L. Kiekens and R. Camcrlynck, 1982. Chemical analysis of plant and soils. Lab. of Analytical and Agro. State Univ. Ghent -Belgium.

Dhugga, K.S. and J.G. Waines, 1989. Analysis of nitrogen accumulation and use in bread and durum wheat. Crop Sci. 29: 1232-1239.

Erley, G.S., H.P. Kaul, M. Kruse and W. Aufhammer, 2005. Yield and nitrogen utilization efficiency of the pseudocereals amaranth, quinoa, and buckwheat under differing nitrogen fertilization. European Journal of Agronomy 22(1): 95-100.

Fakorede, M.A.B. and B.O. Opeke, 1985. Whether factors affecting the response of maize to planting date in a tropical rainforest location. Exp. Agric. 21:31-40.

Geren, H., 2015. Effects of different nitrogen levels on the grain yield and some yield components of quinoa (Chenopodium quinoa Willd.) under Mediterranean climatic conditions. Turkish J. of Field Crops 20(1): 59-64.

Gomez, K.A. and A.A. Gomez, 1984. Statistical Procedures for Agriculture Research. A Wiley-InterScience Publication, John Wiley and Sons, New York.

Guo, X., R. Wang, R. Chang, X. Liang, C. Wang, Y. Luo, Y. Yuan and W. Guo (2014). Effects of nitrogen addition on growth and photosynthetic characteristics of Acer truncatum seedlings. Dendrobiology 72: 151-161.

Havlin, J.L., S.L. Tisdale, J.D. Beaton and W.L. Nelson, 2005. Soil Fertility and Fertilizers: An Introduction to Nutrient Management. Pearson Education, Inc., Upper Saddle River, New Jersey, USA.

ICC standards, 1999. Standard methods of the International Association for Cereal Science and Technology. ICC, Vienna.

Jacobsen, S.E., I. Jørgensen and O. Stølen, 1994. Cultivation of quinoa (Chenopodium quinoa) under temperate climatic conditions in Denmark. Journal of Agricultural Science 122: 47-52. 
Kakabouki, I.P., D. Hela, I. Roussis, P. Papastylianou, A.F. Sestras and D.J. Bilalis, 2018. Influence of fertilization and soil tillage on nitrogen uptake and utilization efficiency of quinoa crop (Chenopodium quinoa Willd.) Journal of Soil Science and Plant Nutrition 18(1): 220-235.

Klute, A. (eds.), 1986. Methods of Soil Analysis (Part 1): Physical and Mineralogical Methods (second edition). American Society of Agronomy Monograph no. 9, American Society of Agronomy, Madison, WI, USA.

Lawlor, D.W., 2002. Carbon and nitrogen assimilation in relation to yield: Mechanisms are the key to understanding production systems. Journal of Experimental Botany 53(370): 773-787.

Leghari, S.J., N.A. Wahocho, G.M. Laghari, A. Laghari, G.M. Bhabhan, K.H. Talpur, T.A. Bhutto, S.A. Wahocho and A.A. Lashari, 2016. Role of nitrogen for plant growth and development: A review. Advances in Environmental Biology 10(9): 209-218.

MacDonald, W.N., T.J. Blom, M.J. Tsujita and B.J. Shelp, 2013. Review: Improving nitrogen use efficiency of potted chrysanthemum: Strategies and benefits. Can. J. Plant Sci. 93: 1009-1016.

Mengel, K and E.A. Kirby, 2001. Principals of Plant Nutrition. Kluwer Academic Publishers, Netherlands.

Meyers, R.L., 1998. Nitrogen fertilizer effect on grain Amaranth. Agronomy Journal 90: 597-602.

Navruz-Varli, S. and N. Sanlier, 2016. Nutritional and health benefits of quinoa (Chenopodium quinoa Willd.). Journal of Cereal Science 69: 371-376.

Novozamsky, I., V. J. G. Houba, R. van Ecka and W. van Vark, 1983. A novel digestion technique for multi element plant analysis. Communications in Soil Science and Plant Analysis. 14(3):239-248.

Page, A.L., R.H. Miller and D.R. Keeney (eds.), 1982. Methods of Soil Analysis: Part 2, Chemical and Microbiological Properties. Agronomy Series No 9. American Society of Agronomy, Madison, WI, USA.

Pathak, R.R., S. Lochab and N. Raghuram, 2011. Plant system: improving plant nitrogen-use efficiency. In: Comprehensive Biotechnology (second edition), by Murray Maoo-Young (ed.), Elsevier, Volume 4, pp. 209-218.

Pearson, D., 1976. The Chemical Analysis of Foods. Longman Group Ltd., Harlow, U.K.

Poonia, A. and A. Upadhayay (2015). Chenopodium album Linn: review of nutritive value and biological properties. J. Food Sc. Technol. 52(7): 3977-3985.

Pospišil, A., M. Pospišil, B. Varga, B and Z. Svecnjak, 2006. Grain yield and protein concentration of two amaranth species (Amaranthus spp.) as influenced by nitrogen fertilization. European Journal of Agronomy 25 (3): 250-253.

Risi, J.C. and N.W. Galwey, 1994. The chenopodium grains of the Andes - Inca crops for modern Agriculture. Advances in Applied Biology 10: 145-216.

Sa-Nguansak, T., 2004. Effect of nitrogen fertilizer on nitrogen assimilation and seed quality of amaranth (Amaranthus spp.) and quinoa (Chenopodium quinoa Willd). Doctoral Dissertation Submitted for the degree of Doctor of Agricultural Sciences of the Faculty of Agricultural Sciences Georg-August-University of Göttingen.

Schulte, A.E.G., H.P. Kaul, M. Kruse and W. Aufhammer, 2005. Yield and nitrogen utilization efficiency of the pseudocereals amaranth, quinoa, and buckwheat under differing nitrogen fertilization. European Journal of Agronomy 22(1): 95-100.

Singh, R.K. and B.D. Chaudhary, 1995. Biometrical methods in quantitative genetic analysis. Kalyani Publishers, New Delhi, pp. 215-218.

Singh, R.K. and S.N. Kakar, 1977. Control on individual trait means during index selection. Proc. Third Cong. SABRAO (Canberra), III Ed, pp. 22-25.

Stahl, A., M. Pfeifer, M. Frich, B. Wittkop and R. J. Snowdon, 2017. Recent genetic gains in nitrogen use efficiency in oilseed rape. Frontiers in Plant Science 8(963): 1-13.

Tillman, B.A., W.L. Pan and S.E. Ullrich, 1991. Nitrogen use by Northern European and Pacific Northwest U.S. barley genotypes under no-till management. Agronomy Journal 83: 194-200.

Vilcacundo, R. and B. Hernandez-Ledesma, 2017. Nutritional and biological value of quinoa (Chenopodium quinoa Willd.). Current Opinion in Food Science 14: 1-6.

Zikankuba, V. and A. James, 2017. Quinoa: A potential crop for food and nutritional security in Tanzania. American Journal of Research Communications 41(1): 15-28. 